\title{
Pengaruh Tipe Kepribadian, Berpikir Divergen, Iklim Keluarga, dan Motivasi Terhadap Prestasi Belajar Matematika Siswa Kelas XI MIPA SMA
}

\author{
Hamzah Upu ${ }^{1, a)}$, Nasrullah ${ }^{1, b)}$, dan Alim Alqadri Amir ${ }^{1, \mathrm{c})}$ \\ ${ }^{1}$ Jurusan Matematika, Fakultas MIPA, Universitas Negeri Makassar \\ a)hamzah.upu@unm.ac.id \\ b) nasrullah@unm.ac.id \\ c) aliemalqadri@gmail.com
}

\begin{abstract}
Abstrak. Penelitian ini adalah penelitian ex-post facto yang bertujuan untuk mengetahui adanya pengaruh antara tipe kepribadian, berpikir divergen, iklim keluarga, dan motivasi terhadap prestasi belajar matematika siswa SMA Negeri di Kabupaten Sinjai. Populasi penelitian adalah siswa kelas XI MIA di salah satu SMA Negeri di Kabupaten Sinjai. Dengan teknik cluster random sampling diperoleh sampel penelitian sebanyak 60 siswa kelas XI SMA Negeri di Kabupaten Sinjai. Data dikumpulkan dengan menggunakan instrumen angket dan tes, kemudian dianalisis dengan menggunakan statistika deskriptif dan inferensial. Hasil penelitian diperoleh bahwa tidak terdapat pengaruh langsung dan tidak langsung tipe kepribadian terhadap prestasi belajar matematika siswa. Selain itu, terdapat pengaruh langsung masing-masing antara motivasi, iklim keluarga dan berpikir divergen terhadap prestasi belajar matematika siswa. Sehingga iklim keluarga dan berpikir divergen masing-masing memiliki pengaruh tidak langsung terhadap prestasi belajar matematika melalui variabel motivasi.
\end{abstract}

Kata Kunci: Tipe Kepribadian, Berpikir Divergen, Iklim Keluarga, Motivasi, Prestasi Belajar Matematika

\begin{abstract}
Abstrack. This study was ex-post facto research which purposed to know the influence of personality type, divergent thinking, family climate, and motivation toward student's mathematics learning achievement on grade XI of Senior High School in Sinjai. The population of this study is student grade 11th MIA Senior High School in Sinjai. The sampling technique in this study was cluster random sampling, so the sample is 60 student grade 11th MIA in Senior High School in Sinjai. The data was collected using a questionnaire and test, then analyzed using descriptive statistics and inferential statistics. The results showed that there was no direct and indirect influence of personality types on students' mathematics learning achievement. In addition, there is a direct influence of each of the motivation, family climate and divergent thinking on the mathematics learning achievement of students. So that the family climate and divergent thinking each have an indirect effect on mathematics learning achievement through motivational variables.
\end{abstract}

Keywords: Personality Type, Divergent Thinking, Family Climate, Motivation, Mathematics Learning Achievement

\section{PENDAHULUAN}

Prestasi belajar yang dimiliki oleh siswa dipengaruhi oleh beberapa faktor, diantaranya faktor internal dan faktor eksternal. Faktor internal adalah faktor yang berasal dari dalam diri peserta didik, sedangkan faktor eksternal adalah faktor yang berasal dari luar peserta didik. Faktor internal yang mempengaruhi prestasi belajar meliputi kemampuan berpikir divergen, motivasi, 
kepribadian, dan lain-lain. Faktor eksternal yang mempengaruhi prestasi belajar meliputi lingkungan keluarga, lingkungan masyarakat, sarana dan prasarana, dan sebagainya.

Salah satu faktor internal yang mempengaruhi prestasi belajar yaitu motivasi yang dimiliki oleh siswa. Motivasi dapat diartikan sebagai suatu tenaga (dorongan, alasan atau kemauan) dari dalam yang menyebabkan seseorang bertindak yang mana tindakan itu diarahkan kepada tujuan tertentu yang hendak dicapai (Slameto, 1995). Sejalan dengan itu, Dwi (2016) berpendapat bahwa dengan motivasi yang tinggi, siswa akan memiliki semangat belajar yang tinggi pula. Hal ini disebabkan karena seseorang yang memiliki motivasi yang tinggi, dapat memotivasi dirinya sendiri untuk bisa mencapai sesuatu yang diharapkan.

Beberapa penelitian telah mengakaji tentang motivasi. Cleopatra (2015) telah melakukan penelitian tentang pengaruh gaya hidup dan motivasi belajar terhadap prestasi belajar. Hasilnya menunjukkan bahwa motivasi belajar memiliki pengaruh yang signifikan terhadap prestasi belajar siswa. Rezeki (2016) meneliti tentang pengaruh motivasi belajar terhadap prestasi belajar siswa. Hasilnya menunjukkan bahwa motivasi belajar berpengaruh positif dan signifikan terhadap prestasi belajar siswa.

Faktor internal kedua yang mempengaruhi prestasi belajar yaitu tipe kepribadian yang dimiliki oleh siswa. Tipe kepribadian dapat dibedakan menjadi dua yaitu tipe kepribadian ekstrovert dan introvert. Setiap tipe kepribadian cenderung memiliki sifat dan cara tersendiri dalam melakukan proses belajarnya. Individu introvert cenderung senang melakukan pekerjaannya seorang diri, berkebalikan dengan individu ekstrovert yang senang mendiskusikan permasalahan yang didapatnya dengan orang lain. Hal ini menunjukkan adanya pengaruh hasil prestasi belajar yang berbeda dari masing-masing individu tersebut (Nursyam \& MS, 2018).

Beberapa penelitian telah mengkaji tentang tipe kepribadian. Sari (2012) telah melakukan penelitian tentang pengaruh tipe kepribadian terhadap hasil belajar. Penelitian ini dilakukan di dua sekolah SMP Swasta di Medan. Penelitian tersebut menemukan adanya perbedaan hasil belajar yang diperoleh siswa. Kumala (2012) meneliti tentang pengaruh kepribadian terhadap motivasi mahasiswa. Hasilnya menunjukan responden yang memiliki kepribadian introvert mempunyai motivasi yang lebih tinggi dibandingkan dengan responden yang berkepribadian ekstrovert.

Faktor lain yang juga mempengaruhi prestasi belajar siswa yaitu kemampuan berpikir divergen. Hal ini disebabkan karena kemampuan berpikir divergen akan dapat melihat permasalahan dari banyak perspektif, sebab seseorang yang berpikir divergen akan menghasilkan lebih banyak alternatif jawaban untuk memecahkan suatu masalah. Hal ini berguna dalam menjawab pertanyaan yang beragam dan kompleks, sehingga dapat meningkatkan prestasi belajarnya (Agustini, 2016).

Beberapa penelitian telah mengkaji tentang berpikir divergen. Nursyidah (2016) telah melakukan penelitian tentang pengaruh berpikir divergen terhadap hasil belajar. Dari hasil uji hipotesis didapatkan hasil bahwa berpikir divergen berpengaruh positif terhadap hasil belajar. Nurdiansyah (2016) meneliti tentang pengaruh berpikir divergen terhadap prestasi belajar siswa. Hasil penelitian tersebut menunjukkan bahwa berpikir divergen berpengaruh secara signifikan terhadap prestasi belajar siswa.

Selain faktor internal, iklim keluarga sebagai faktor eksternal juga mempengaruhi keberhasilan siswa dalam belajar. Iklim keluarga yang berkaitan dengan suasana dalam keluarga memiliki peranan penting dalam menumbuhkan motivasi dalam diri siswa. Hal ini dikarenakan apabila dalam keluarga seseorang selalu mendapatkan perhatian, kasih sayang, dorongan, kepercayaan, dan suasana yang nyaman, maka akan memberikan peningkatan motivasi bagi seseorang siswa untuk terus berprestasi (Slameto, 1995).

Beberapa penelitian telah meneliti tentang iklim keluarga. Nursyam (2018) telah melakukan penelitian tentang pengaruh iklim keluarga terhadap prestasi belajar matematika siswa. Hasilnya menunjukkan bahwa adanya pengaruh iklim keluarga terhadap prestasi belajar 
matematika siswa. Mustakim (2016) meneliti tentang pengaruh iklim keluarga terhadap prestasi belajar. Hasilnya menunjukkan bahwa iklim keluarga berupa perhatian orang tua, relasi antara keluarga dan suasana rumah mempunyai pengaruh terhadap peningkatan prestasi peserta didik

Penelitian ini berfokus pada tiga faktor internal yaitu tipe kepribadian, berpikir divergen, motivasi dan satu faktor eksternal yaitu iklim keluarga. Adapun tujuan dari penelitian ini yaitu untuk mengetahui pengaruh langsung maupun tidak langsung keempat faktor tersebut terhadap prestasi belajar.

\section{KAJIAN PUSTAKA}

\section{Tipe Kepribadian}

Kepribadian manusia terbagi menjadi dua tipe, yaitu ekstrovert dan introvert. Kepribadian ekstrovert dapat diartikan sebagai kecenderungan seseorang dalam menunjukkan sikap yang lebih terbuka dan mau menerima masukan dari pihak luar, aktif, dan suka berteman. Sedangkan kepribadian introvert menurut Djalii adalah kecenderungan seseorang untuk menarik diri dari lingkungan sosialnya, serta minat, sikap, dan keputusan yang diambil selalu didasarkan pada perasaan, pemikiran, dan pengalamannya sendiri (Djalii, 2007).

Beberapa penelitian telah mengkaji tentang tipe kepribadian. Kumala (2012) meneliti tentang pengaruh kepribadian terhadap motivasi mahasiswa. Peneltian tersebut menemukan responden berkepribadian ekstrovert sebanyak 48 orang dan responden yang berkepribadian introvert sebanyak 21 orang. Responden dengan motivasi tinggi sebanyak 40 orang, motivasi sedang 29 orang dan tidak ada responden dengan motivasi rendah. Dari 21 mahasiswa yang berkepribadian introvert lebih banyak yang memiliki motivasi sedang yaitu 19 orang. Dari 48 mahasiswa yang berkepribadian ekstrovert lebih banyak yang memiliki motivasi tinggi, yaitu 38 orang.

Hal senada juga dilakukan oleh Sari (2012). Ia telah melakukan penelitian tentang pengaruh tipe kepribadian terhadap hasil belajar. Penelitian ini dilakukan di dua sekolah SMP Swasta di Medan. Penelitian tersebut menemukan adanya perbedaan hasil belajar yang diperoleh siswa, dimana siswa dengan tipe kepribadian introvert menunjukkan hasil belajar yang lebih tinggi dibandingkan dengan siswa yang memiliki kepribadian ekstrovert.

\section{Berpikir Divergen}

Berpikir divergen sebagai proses berpikir yang berorientasi pada penemuan jawaban atau alternatif yang banyak, dimana otak dibiarkan bergerak ke berbagai arah untuk mencapai ide-ide yang nantinya akan ditampung (Ismayanti, 2016). Sedangkan menurut Nyanyu (2014) berpendapat bahwa berpikir divergen yaitu pola berpikir seseorang yang lebih didominasi oleh berfungsinya belahan otak kanan, berpikir lateral, menyangkut pemikiran sekitar atau yang menyimpang dari pusat persoalan.

Dalam menyelesaikan sebuah permasalahan, siswa perlu menemukan banyak cara dalam menyelesaikan permasalahan dan tidak hanya berpatokan dengan satu jawaban saja. Hal ini akan berguna dalam menjawab pertanyaan yang berhubungan dengan matematika karena sifatnya yang abstrak dan kompleks. Dengan demikian, siswa yang memilki kemampuan berpikir divergen akan mempunyai prestasi belajar yang lebih tinggi dibandingkan dengan siswa yang tidak memiliki kemampuan berpikir tersebut (Nursyidah, 2016).

Beberapa penelitian telah mengkaji tentang kemampuan berpikir divergen. Nurdiansyah (2016) meneliti tentang pengaruh berpikir divergen terhadap hasil belajar matematika. Penelitian tersebut dilakukan di tiga sekolah di kecamatan Bontotiro kabupaten Bulukumba dangan sampel sebanyak 117 siswa. Hasil penelitian tersebut menunjukkan bahwa berpikir divergen berpengaruh secara signifikan terhadap prestasi belajar siswa. 
Hal senada juga dilakukan Faizah (2012). Ia melakukan penelitian tentang profil kemampuan berpikir divergen dalam menyelesaikan masalah Open-Ended. Penelitian tersebut dilakukan di salah satu SMP Negeri di Sidoarjo. Penelitian tersebut menemukan bahwa kemampuan berpikir divergen siswa dalam mengembangkan cara yang berbeda untuk menyusun alternatif penyelesaian dikatakan masih kurang meluas. Hal ini dikarenakan siswa masih kesulitan dalam memandang suatu permasalahan dari beberapa sisi. Siswa dikatakan memiliki kemampuan berpikir divergen jika mampu memandang permasalahan dari beberapa sisi dan dapat menyelesaikan masalah dengan beberapa teknik sehingga dapat mengembangkan cara-cara lain dengan pendekatan yang berbeda.

\section{Iklim Keluarga}

Iklim keluarga merupakan impilikasi teori iklim organisasi yang dikaitkan dengan lingkungan keluarga. Konsep iklim sering digambarkan sebagai suatu kebiasaan atau sering diistilahkan sebagai suasana. Pada setiap keluarga terdapat wilayah iklim yang khas. Iklim itu menciptakan kondisi bagi lahirnya perbuatan-perbuatan tertentu bagi setiap anggota keluarga. (Mustakim, 2016). Slameto (1995) mengartikan iklim keluarga sebagai iklim kehidupan di dalam keluarga yang terkait dengan perhatian orangtua, suasana rumah dan relasi antar keluarga. Slameto juga menyatakan bahwa siswa yang belajar akan menerima pengaruh dari keluarga berupa cara orang tua mendidik anak, relasi antara anggota keluarga, suasana rumah tangga dan keadaan ekonomi keluarga.

Beberapa penelitian telah mengkaji tentang iklim keluarga. Violita (2013) meneliti tentang pengaruh lingkungan keluarga terhadap prestasi belajar. Hasilnya menunjukkan bahwa lingkungan keluarga berupa perhatian dan pengawasan dalam belajar mempunyai pengaruh terhadap peningkatan prestasi peserta didik. Begitu juga dengan fasilitas belajar yang dimiliki dan dimanfaatkan oleh siswa dalam belajar akan berpengaruh terhadap prestasi siswa.

Hal senada juga dilakukan Nursyam (2018). Ia telah melakukan penelitian tentang pengaruh iklim keluarga terhadap prestasi belajar matematika siswa. Penelitian ini dilakukan di tiga SMP Negeri di kabupaten Bone dengan sampel sebanyak 262 siswa. Hasilnya menunjukkan bahwa adanya pengaruh iklim keluarga terhadap prestasi belajar matematika siswa.

\section{Motivasi}

Motivasi berasal dari kata motif, yang sering diartikan sebagai daya dalam diri seseorang untuk melakukan sesuatu. Motif menurut Haling (2017) adalah sebab yang menjadi dorongan tindakan seseorang. Motif diartikan sebagai daya penggerak dari dalam diri subjek untuk melakukan aktivitas tertentu demi mencapai suatu tujuan. Motif menjadi aktif pada saat tertentu, terutama bila kebutuhan untuk mencapai tujuan dapat dirasakan atau mendesak.

Dalam kegiatan pembelajaran, motivasi dapat dikatakan sebagai keseluruhan daya penggerak dalam diri siswa yang menimbulkan, menjamin kelangsungan dan memberikan arah kegiatan belajar, sehingga diharapkan tujuan yang ada dapat tercapai. Menurut Dwi (2016) dengan motivasi yang tinggi, siswa akan memiliki semangat belajar yang tinggi pula, karena seseorang yang memiliki motivasi, dapat memotivasi dirinya sendiri untuk bisa mencapai sesuatu yang diharapkan sehingga ia tidak mudah putus asa. Hal ini pada akhirnya akan memberikan dampak pada prestasi belajarnya.

Beberapa penelitian telah mengkaji tentang motivasi. Sukenada (2013) meneliti tentang pengaruh motivasi berprestasi terhadap hasil belajar seni budaya siswa. Penelitian tersebut dilakukan di salah satu SMA di tabanan dengan sampel sebanyak 170 siswa. Penelitian ini menemukan adanya hubungan positif yang signifikan antara motivasi berprestasi terhadap hasil belajar seni budaya siswa. Hal ini menunjukkan bahwa peningkatan motivasi siswa dapat menaikkan pula hasil belajar yang diperoleh siswa. 
Hal senada juga dilakukan oleh Daud (2012). Ia meneliti tentang pengaruh motivasi belajar terhadap hasil belajar siswa. Penelitian tersebut dilakukan di salah satu SMA di Palopo. Hasil penelitian tersebut menunjukkan bahwa motivasi belajar siswa berada pada kategori sedang sampai tinggi. Motivasi belajar ini didasarkan oleh keinginan untuk kebutuhan kinerja, penghargaan, tantangan, tanggungjawab, keterlibatan, dan kesempatan.

\section{METODE PENELITIAN}

Jenis penelitian yang digunakan adalah jenis penelitian ex post facto yang bersifat kausalitas. Penelitian ini dilaksanakan di dua kelas XI pada salah satu SMA Negeri di Kabupaten Sinjai. Sampel pada penelitian ini sebanyak 60 orang. Variabel yang diselidiki dalam penelitian ini yaitu tipe kepribadian $\left(X_{1}\right)$, berpikir divergen $\left(X_{2}\right)$, iklim keluarga $\left(X_{3}\right)$, motivasi $\left(X_{4}\right)$, dan prestasi belajar matematika (Y). Adapun desain keterkaitan antar variabel-variabel penelitian ditunjukkan pada Gambar 1.

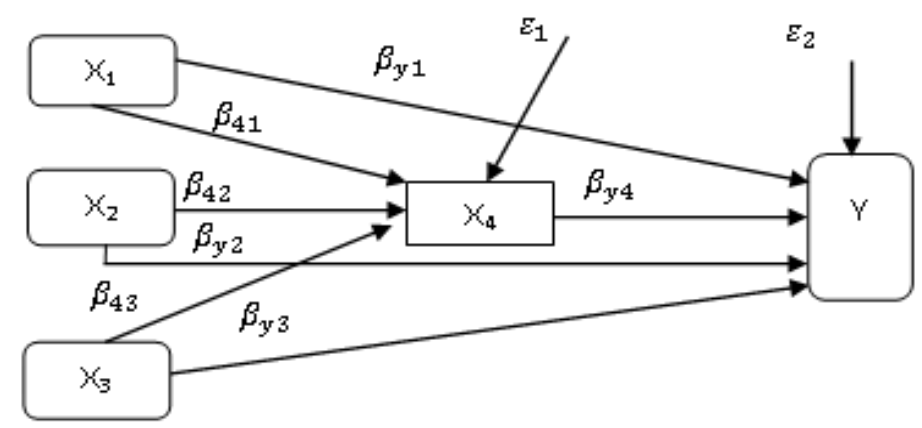

GAMBAR 1. Desain Penelitian

Keterangan : $\quad \mathrm{X}_{1}=$ tipe kepribadian

$$
\begin{aligned}
& \mathrm{X}_{2}=\text { berpikir divergen } \\
& \mathrm{X}_{3}=\text { iklim keluarga } \\
& \mathrm{X}_{4}=\text { motivasi } \\
& \mathrm{Y}=\text { prestasi belajar matematika } \\
& \varepsilon=\text { error/variabel residu } \\
& \beta=\text { koefisien jalur }
\end{aligned}
$$

Berdasarkan diagram jalur pada Gambar 1, dapat dituliskan persamaan model strukturalnya sebagai berikut:

$$
\begin{aligned}
& X_{4}=\beta_{41} x_{1}+\beta_{42} x_{2}+\beta_{43} x_{3}+\varepsilon_{1} \\
& Y=\beta_{y 1} x_{1}+\beta_{y 2} x_{2}+\beta_{y 3} x_{3}+\beta_{y 4} x_{4}\left(\beta_{y 1} x_{1}+\beta_{y 2} x_{2}+\beta_{y 3} x_{3}\right)+\varepsilon_{2}
\end{aligned}
$$

Teknik pengumpulan data yang digunakan pada penelitian ini, yaitu berupa angket dan tes. Adapun Instrumen yang digunakan berupa angket tipe kepribadian, tes berpikir divergen, angket iklim keluarga, angket motivasi dan tes prestasi belajar matematika yang telah divalidasi oleh dua orang ahli.

Analisis data yang digunakan pada penelitian ini yaitu analisis statistik deskriptif dan analisis statistik inferensial. Analisis statistik deskriptif digunakan untuk mendeskripsikan setiap variabel penelitian yaitu tipe kepribadian, berpikir divergen, iklim keluarga, motivasi dan prestasi belajar matematika siswa. Hasil analisis statistik deskriptif meliputi tabel distribusi frekuensi, mean, variansi, standar deviasi, dan perhitungan presentase.

Analisis statistik inferensial digunakan untuk menguji hipotesis penelitian. Adapun hipotesis dalam penelitian ini yaitu terdapat pengaruh langsung dan pengaruh tidak langsung tipe kepribadian, berpikir divergen, dan iklim keluarga terhadap prestasi belajar matematika melalui 
variabel motivasi. Metode analisis yang digunakan dalam penelitian ini adalah analisis kuantitatif dengan analisis jalur (path analysis) pada taraf kepercayaan 95\% $(\alpha=0.05)$, namun sebelumnya dilakukan uji prasyarat yaitu uji normalitas, uji multikolinearitas, dan uji heteroskedastisitas.

\section{HASIL DAN PEMBAHASAN}

\section{Analisis Statistik Deskriptif}

TABEL 1. Distribusi frekuensi skor tipe kepribadian

\begin{tabular}{ccc}
\hline & Frekuensi & Persentase \\
\hline Introvert & 35 & $58.33 \%$ \\
Ekstrovert & 25 & $41.67 \%$ \\
Jumlah & 60 & $100 \%$ \\
\hline
\end{tabular}

Tabel 1 menunjukkan bahwa siswa sebanyak 25 orang siswa memiliki tipe kepribadian ekstrovert. Namun secara umum siswa tergolong memilki tipe kepribadian introvert dengan persentase sebesar 58.33\%.

TABEL 2. Distribusi frekuensi skor berpikir divergen

\begin{tabular}{|c|c|c|c|}
\hline Interval nilai & Kategori & Frekuensi & Persentase (\%) \\
\hline $90-100$ & Sangat tinggi & 0 & $0 \%$ \\
\hline $80-89$ & Tinggi & 14 & $23.33 \%$ \\
\hline $66-79$ & Sedang & 35 & $58.33 \%$ \\
\hline $55-65$ & Rendah & 0 & $0 \%$ \\
\hline $0-54$ & Sangat rendah & 11 & $18.33 \%$ \\
\hline \multicolumn{2}{|c|}{ Jumlah } & 60 & $100 \%$ \\
\hline
\end{tabular}

Pada Tabel 2, terlihat bahwa tidak ada siswa yang memiliki kemampuan berpikir divergen pada kategori rendah dan sangat tinggi. Namun, secara umum kemampuan berpikir divergen siswa berada pada kategori sedang dengan persentase sebesar 58.33\%.

TABEL 3. Distribusi frekuensi skor iklim keluarga

\begin{tabular}{cccc}
\hline Interval Nilai & Kategori & Frekuensi & Persentase (\%) \\
\hline $24.00-38.03$ & Sangat Rendah & 0 & 0 \\
$38.04-65.13$ & Rendah & 22 & $36.67 \%$ \\
$65.14-92.59$ & Tinggi & 38 & $63.33 \%$ \\
$92.60-106.98$ & Sangat Tinggi & 0 & 0 \\
\hline \multicolumn{2}{c}{ Jumlah } & 60 & $100 \%$ \\
\hline
\end{tabular}

Pada Tabel 3, dapat ditinjau bahwa tidak ada siswa yang memiliki iklim keluarga dalam kategori sangat rendah dan rendah. Namun, secara umum iklim keluarga yang siswa miliki berada pada kategori tinggi dengan persentase sebesar $63.33 \%$.

TABEL 4. Distribusi frekuensi skor motivasi

\begin{tabular}{cccc}
\hline Interval Nilai & Kategori & Frekuensi & Persentase (\%) \\
\hline $25.00-40.91$ & Sangat Rendah & 0 & 0 \\
$40.92-70.32$ & Rendah & 20 & $33.33 \%$ \\
$70.33-101.37$ & Tinggi & 36 & $60 \%$ \\
$101.38-118.92$ & Sangat Tinggi & 4 & $6.67 \%$ \\
\hline \multicolumn{2}{c}{ Jumlah } & 60 & $100 \%$ \\
\hline
\end{tabular}

Tabel 4 menunjukkan bahwa tidak ada siswa yang memiliki motivasi pada kategori sangat rendah dan hanya 4 orang siswa yang memiliki motivasi sangat tinggi. Namun secara umum motivasi siswa berada pada kategori tinggi dengan persentase sebesar $60 \%$. 
TABEL 5. Distribusi frekuensi skor prestasi belajar matematika

\begin{tabular}{cccc}
\hline Interval nilai & Kategori & Frekuensi & Persentase (\%) \\
\hline $85-100$ & Sangat tinggi & 10 & $16.67 \%$ \\
$70-84$ & Tinggi & 22 & $36.67 \%$ \\
$54-69$ & Sedang & 13 & $21.67 \%$ \\
$40-55$ & Rendah & 8 & $13.33 \%$ \\
$0-39$ & Sangat rendah & 7 & $11.67 \%$ \\
& Jumlah & 60 & $100 \%$ \\
\hline
\end{tabular}

Tabel 5 menunjukkan bahwa terdapat 7 siswa yang berada pada kategori sangat rendah, sedangkan 10 siswa berada pada kategori sangat tinggi. Namun secara umum prestasi belajar matematika siswa berada pada kategori tinggi dengan persentase sebesar 36.67\%.

\section{Analisis Statistik Inferensial}

TABEL 6. Hasil analisis regresi variabel bebas dengan variabel antara

\begin{tabular}{lcc}
\hline \multicolumn{1}{c}{ Model } & Beta & Sig. \\
\hline 1 (Constant) & & 0.034 \\
Tipe Kepribadian & -0.117 & 0.162 \\
Berpikir Divergen & 0.399 & 0.001 \\
Iklim Keluarga & 0.435 & 0.000 \\
\hline
\end{tabular}

Pada Tabel 6, dapat dilihat bahwa nilai signifikansi variabel tipe kepribadian sebesar 0.162 lebih besar dari alpha 0.05 . Hal ini menunjukkan bahwa tidak terdapat pengaruh langsung tipe kepribadian terhadap motivasi. Selain itu, variabel berpikir divergen dan iklim keluarga memiliki nilai signifikansi masing-masing sebesar 0.001 dan 0.000 yang lebih kecil dari alpha 0.05. Hal ini menunjukkan bahwa terdapat pengaruh langsung masing-masing antara berpikir divergen dan iklim keluarga terhadap motivasi.

TABEL 7. Hasil analisis regresi variabel bebas dengan variabel terikat

\begin{tabular}{llc}
\hline \multicolumn{1}{c}{ Model } & Beta & Sig. \\
\hline 1 (Constant) & & 0.000 \\
Tipe Kepribadian & 0.024 & 0.726 \\
Berpikir Divergen & 0.356 & 0.001 \\
Iklim Keluarga & 0.382 & 0.000 \\
Motivasi & 0.242 & 0.027 \\
\hline
\end{tabular}

Pada Tabel 7, dapat dilihat bahwa nilai signifikansi dari variabel tipe kepribadian sebesar 0.726 lebih besar dari alpha 0.05. Hal ini menunjukkan bahwa tidak terdapat pengaruh langung antara tipe kepribadian terhadap prestasi belajar matematika. Selain itu, variabel berpikir divergen, iklim keluarga dan motivasi masing-masing memiliki nilai signifikansi sebesar 0.001, 0.000, dan 0.027 lebih besar dari alpha 0.05 . Hal ini menunjukkan bahwa terdapat pengaruh langsung masing-masing antara berpikir divergen, iklim keluarga, dan motivasi terhadap prestasi belajar matematika.

Pengaruh tidak langsung dapat dlihat dari nilai hasil kali antara koefisien beta tipe kepribadian, berpikir divergen, dan iklim keluarga dengan koefisien beta variabel motivasi. Dengan demikian, variabel tipe kepribadian memiliki nilai hasil kali keofisien beta sebesar -0.117 lebih kecil dari 0 . Hal ini menunjukkan bahwa tidak terdapat pengaruh tidak langsung antara tipe kepribadian terhadap prestasi belajar matematika melalui variabel motivasi. Selain itu, variabel berpikir divergen dan iklim keluarga masing-masing memiliki nilai hasil kali keofisien beta sebesar 0.097 dan 0.105 lebih besar dari 0 . Hal ini menunjukkan bahwa terdapat pengaruh tidak langsung masing-masing antara variabel berpikir divergen dan iklim keluarga terhadap prestasi belajar matematika melalui variabel motivasi. 
Gambar 2 menunjukkan diagram model jalur penuh pengaruh variabel tipe kepribadian $\left(\mathrm{X}_{1}\right)$, berpikir divergen $\left(\mathrm{X}_{2}\right)$, iklim keluarga $\left(\mathrm{X}_{3}\right)$ dan motivasi $\left(\mathrm{X}_{4}\right)$ terhadap prestasi belajar matematika (Y) siswa.

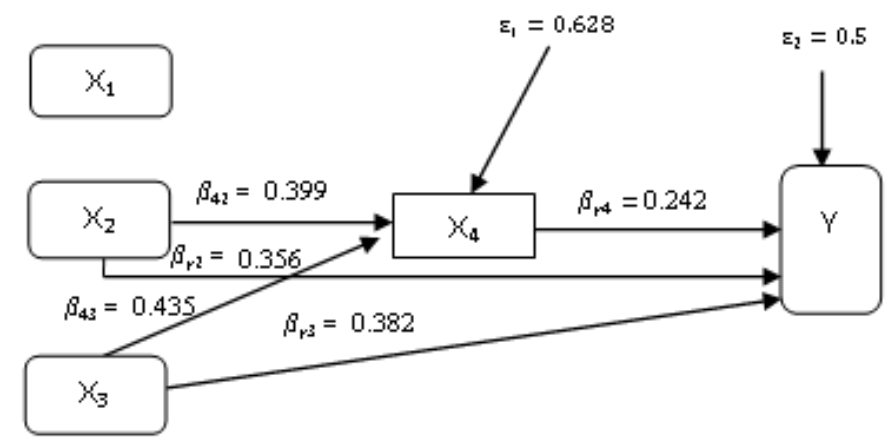

GAMBAR 2. Model jalur penuh variabel-variabel penelitian

Keterangan : $\quad \mathrm{X}_{1}=$ tipe kepribadian

$\mathrm{X}_{2}=$ berpikir divergen

$\mathrm{X}_{3}=$ iklim keluarga

$\mathrm{X}_{4}=$ motivasi

$\mathrm{Y}=$ prestasi belajar matematika

$\varepsilon=$ error/variabel residu

$\beta=$ koefisien jalur

Pada Gambar 2, terlihat bahwa berpikir divergen dan iklim keluarga mempengaruhi motivasi dengan kontribusi masing-masing sebesar $39.9 \%$ dan $43.5 \%$. Selain itu, berpikir divergen, iklim keluarga dan motivasi juga mempengaruhi prestasi belajar dengan kontribusi masing-masing sebesar $35.6 \%, 38.2 \%$ dan $24.2 \%$.

\section{KESIMPULAN}

Tujuan dari penelitian ini untuk melihat apakah ada pengaruh langsung dan tidak langsung antara tipe kepribadian, berpikir divergen, iklim keluarga dan motivasi terhadap prestasi belajar matematika siswa. Hasil penenilan ini menunjukkan bahwa :

1. Tidak terdapat pengaruh langsung dan tidak langsung tipe kepribadian terhadap prestasi belajar matematika siswa.

2. Terdapat pengaruh langsung masing-masing antara motivasi, iklim keluarga dan berpikir divergen terhadap prestasi belajar matematika siswa.

3. Terdapat pengaruh tidak langsung masing-masing antara iklim keluarga dan berpikir divergen terhadap prestasi belajar matematika melalui variabel motivasi.

Penelitian ini mengkaji tentang pengaruh tipe kepribadian, berpikir divergen, iklim keluarga dan motivasi terhadap prestasi belajar matematika siswa. Penelitian lain yang dapat dikembangkan adalah penelitian yang bertujuan untuk mencari tahu bagaimana keempat faktor tersebut mempengaruhi prestasi belajar matematika secara kuantitatif.

\section{DAFTAR PUSTAKA}

Agustini, B. N. (2016). Pengaruh Potensi Akademik, Kemampuan Berpikir Divergen, dan Kemandirian Belajar Terhadap Prestasi Belajar Matematika Siswa Kelas IX SMP Negeri 2 Sengkang. (Skripsi). Universitas Negeri Makassar, Makassar. 
Cleopatra, M. (2015). Pengaruh Gaya Hidup dan Motivasi terhadap Prestasi Belajar Matematika. Jurnal Formatif,5(2). 168-181.

Djalii. (2007). Psikologi Pendidikan. Jakarta: Bumi Aksara.

Daud, M. (2012). Pengaruh Kecerdasan Emotional dan Motivasi Belajar terhadap Hasil Belajar Biologi Siswa SMA Negeri 3 Kota Palopo. Jurnal Pendidikan dan Pembelajaran, 19(2). 243-255

Dwi, N. M. (2016). Pengaruh konsep diri, Efikasi Diri dan Motivasi terhadap Hasil Belajar Matematika Siswa Kelas XI IPA SMA Negeri 7 Mallawa Maros. (Skripsi). Universitas Negeri Makassar, Makassar.

Faizah, U. (2018). Profil Kemampuan Berpikir Divergen Siswa dalam Menyelesaikan Masalah OPEN ENDED. (Skripsi). Universitas Islam Negeri Sunan Ampel, Surabaya.

Haling, A. (2017). Belajar dan Pembelajaran. Makassar : Badan Penerbit UNM.

Ismayanti, M. (2015). Pengaruh Faktor-faktor Pembangun Kecemasan Belajar dan Efikasi Diri terhadap Prestasi Belajar Matematika melalui Kemampuan Berpikir Divergen pada Siswa Kelas VII SMP Negeri Di Kota Makassar.(Tesis). Universitas Negeri Makassar, Makassar.

Kumala. (2012). Hubungan Antara Tipe Kepribadian dengan Motivasi Mahasiswa Semester VIII Program Studi Ilmu Keperawatan Fakultas Kedokteran Universitas Udayana. (Skripsi). Universitas Udayana, Bali.

Mustakim, A. (2016). Pengaruh Iklim Keluarga, Kebiasan Belajar, Kecerdasan Emosional terhadap Prestasi Belajar Matematika Siswa Kelas XI SMA NEGERI 1 BUNGORO . (Skripsi). Universitas Negeri Makassar, Makassar.

Nurdiansyah, E. (2016). Pengaruh Kecerdasan Spritual, Kecerdasan Emosional, Dampak Negatif Jejaring Sosial, dan Kemampuan Berpikir Divergen terhadap Hasil Belajar Matematika Siswa. Journal of EST, 2(3). 171-184.

Nursyam, A., \& MS, A. T. (2018). Pengaruh Iklim Keluarga terhadap Prestasi Belajar Matematika Siswa SMP. Prosiding Seminar Nasional Pendidikan, 56-70.

Nursyidah. (2016). Pengaruh Kepribadian, Regulasi Diri, Berpikir Divergen dan Kemampuan Komunikasi Matematika terhadap Hasil Belajar Matematika Siswa Kelas XI IPA SMA Negeri di Kabupaten Bantaeng. (Skripsi). Universitas Negeri Makassar, Makassar.

Nyanyu, K. (2014). Psikologi Pendidikan. Jakarta: Raja grafindo.

Rezeki, R. (2016). Pengaruh Kemampuan Awal, Kecerdasan Adversitas, Motivasi Belajar dan Kompetensi Guru terhadap Prestasi Belajar Matematika Siswa Kelas XI IPA SMAN Di Kecamatan Panca Rijang Kabupaten Sidrap. (Skripsi). Universitas Negeri Makassar, Makassar.

Sari, S. W. (2012). Pengaruh Model Pembelajaran dan Tipe kepribadian. Jurnal Tabularasa PPS UNIMED, 9(1). 33-44.

Slameto. (1995). Belajar dan Faktor-faktor yang mempengaruhinya. Jakarta: Rineka Cipta.

Sukenada, I. (2013). Kontribusi Motivasi Berprestasi, Iklim Keluarga, dan Disiplin Belajar terhadap Hasil Belajar Pendidikan Seni Budaya Pada Siswa Kelas XI SMA Negeri 2 Tabanan. e-Jurnal Program Pasca Sarjana Universitas Pendidikan Ganesha, 4(1).

Violita, F. (2013). Pengaruh Lingkungan Keluarga dan Fasilitas Belajar terhadap Prestasi Belajar Siswa Kelas X Administrasi Perkantoran di SMKN 1 Payakumbuh. (Skripsi,). Universitas Negeri Padang, Padang. 